\title{
Analysis of the Spatial Distribution of Settlements of Red Wood Ants in the Baikal Region
}

\author{
Igor A. Antonov*a, \\ Roman K. Fedorov ${ }^{b}$ and Innokentiy A. Bashalkhanov \\ ${ }^{a}$ Siberian Institute of Plant Physiology \\ and Biochemistry SB RAS \\ 132 Lermontov Str., Irkutsk, 664033, Russia \\ ${ }^{b}$ Matrosov Institute for System Dynamics \\ and Control Theory SB RAS \\ 134 Lermontov Str., Irkutsk, 664033, Russia \\ 'Scientific and Production Company \\ "Regional Ecological Forecast" \\ 222 Bauman Str., Irkutsk, 664053, Russia
}

Received 21.06.2018, received in revised form 06.12.2018, accepted 14.02.2019

Outbreaks of defoliating insects constantly emerge and spread in the heavily forested Baikal region. Biological control is the approach of choice in pest management, and red wood ants are used to control defoliating insects at their outbreak sites. The purpose of the present paper is to choose the forest plots with complexes of red wood ant nests in the Baikal region and to estimate the level of protection of these plots from defoliating insects using hybrid geoinformation system (GIS). The Institute for System Dynamics and Control Theory SB RAS geoportal (http://geos.icc.ru) is the hybrid GIS. During fieldwork, 101 nests of F. aquilonia Yarr. and 20 nests of F. lugubris Zett. were found. One hundred and two nests ( $88 \mathrm{~F}$. aquilonia nests and $14 \mathrm{~F}$. lugubris nests) formed nest complexes and were located on 18 forest plots. Two parameters were used to estimate protection level of forest plots from defoliating insects: the average number of nests per 1 hectare (settlement density) and the total area of dome bases of all anthills located on 1 hectare (power of the nest complex). The research revealed that only four forest plots ("Uzury", "Khalgay", "Onguren_2", and "Onguren_3"), situated in the mountain taiga pine landscape, were protected from defoliating insects (settlement density $\geq 5$ nests/ha and power of nest complex $>6 \mathrm{~m}^{2} / \mathrm{ha}$ ). Besides, the complex of nests in the "Onguren_2" forest plot can be a source for capture of filial nests. The "Arshan_2" forest plot, situated in the mountain taiga dark coniferous landscape of reduced development, had the lowest density of settlements of ants (less

(C) Siberian Federal University. All rights reserved

This work is licensed under a Creative Commons Attribution-NonCommercial 4.0 International License (CC BY-NC 4.0).

* Corresponding author E-mail address: patologi@sifibr.irk.ru

ORCID: 0000-0001-6483-4504 (Antonov I.) 
than two nests per hectare). The state-of-the-art hybrid GIS is a tool that can be used to quickly and efficiently discover and analyze the spatial distribution of settlements of red wood ants.

Keywords: biological forest control, Formica rufa group, settlement density, power of nest complex, hybrid geoinformation system.

Citation: Antonov I.A., Fedorov R.K., Bashalkhanov I.A. Analysis of the spatial distribution of settlements of red wood ants in the Baikal region. J. Sib. Fed. Univ. Biol., 2019, 12(4), 385-397. DOI: 10.17516/1997-1389-0309

\title{
Анализ пространственного \\ распределения поселений рыжих лесных муравьев \\ в Байкальском регионе
}

\author{
И.А. Антонов ${ }^{a}$, \\ Р.К. Федоров ${ }^{\sigma}$, И.А. Башалханов ${ }^{\text {в }}$ \\ ${ }^{a}$ Сибирский институт физиологии \\ и биохимии растений СО РАН \\ Россия, 664033, Иркутск, ул. Лермонтова, 132 \\ ${ }^{6}$ Институт динамики систем и теории управления \\ им. В.М. Матросова СО РАН \\ Россия, 664033, Иркутск, ул. Лермонтова, 134 \\ ${ }^{6}$ ООО Научно-производственная фирма \\ "Региональное экологическое прогнозирование" \\ Россия, 664053, Иркутск, ул. Баумана, 222
}

В Байкальском регионе, обладающем высокой лесистостью, постоянно возникают и действуют очаги массового размножения опасных видов насекомых-филлофагов. Для борьбы с такими вредителями леса наиболее предпочтительными являются биологические средства, $\kappa$ которым относят рыжих лесных муравьев. Эти насекомые успешно используются в качестве энтомофагов в очагах массового размножения вредителей леса. Цель работь на территории Байкальского региона выявить лесные участки с комплексами гнезд рыжих лесных муравьев и оценить уровень защищенности этих участков от насекомых-филлофагов с использованием гибридной геоинформачионной системы (ГИС). В качестве гибридной ГИС применен геопортал Института динамики систем и теории управления СО РAH (http://geos.icc. ru). В ходе полевых работ найдено 101 гнездо Formica aquilonia Yarr. и 20 гнезд F. lugubris Zett. В результате определения участков с комплексами муравейников отмечено, что 102 гнезда сформировали гнездовые комплексы на 18 лесных участках. Для оценки уровня защцщенности участков использовали два параметра - среднее число гнезд на 1 га (плотность поселения) и сумма площадей оснований куполов всех муравейников, расположенных на 1 га (мощңность комплекса). В результате исследования выявлено, что только лесные участки «Узурыл», 
«Халгай», «Онгурен_2»и «Онгурен_3», расположенные вгорно-таежном сосновомландшафте, защищены от существенных повреждений насекомыми-филлофагами. При этом комплекс муравейников на участке «Онгурен_2» может служить базой для взятия искусственных отводков. Самой низкой плотностью поселения муравьев отличался участок «Аршан_2»в горно-таежном темнохвойном ландшафте редуиированного развития. Применение гибридной ГИС, основанной на современных стандартах, дает возможность быстро и эффективно вылвлять и анализировать пространственное распределение поселений рыжих лесных муравьев.

Ключевые слова: биологическая защита леса, групnа Formica rufa, плотность поселения, мощность гнездового комплекса, гибридная ГИС.

Цитирование: Антонов, И.А. Анализ пространственного распределения поселений рыжих лесных муравьев в Байкальском регионе / И.А. Антонов, Р.К. Федоров, И.А. Башалханов // Журн. Сиб. федер. ун-т. Биология, 2019. 12(4). C. 385-397. DOI: 10.17516/1997-1389-0309

\section{Введение}

Байкальский регион обладает сложным рельефом, неоднородностью климата, большим разнообразием почвенного и растительного покрова. Его средняя лесистость составляет 75,8 \%, причем в Иркутской области она достигает 82,9 \% - самый высокий показатель в России (Природные ресурсы, 2009). В этом регионе постоянно возникают и действуют очаги массового размножения опасных видов насекомых-филлофагов (например, сибирский шелкопряд), наносящих большой ущерб лесному хозяйству (Плешанов, 1982). Для борьбы с такими вредителями леса наиболее предпочтительны биологические средства, поскольку применение химического метода сопровождается серьезными негативными побочными воздействиями на лесные экосистемы и приводит к устойчивости вредителей к инсектицидам (Niu et al., 2014).

К числу биологических средств относят муравьев, успешно применяемых в качестве энтомофагов в очагах массового размножения вредителей леса (Żmihorski, 2010; Ramos et al., 2012). При этом часто используют муравьев группы Formica rufa L. (рыжие лесные мура- вьи), в которую входят четыре вида: Formica aquilonia Yarr., F. lugubris Zett., F. polyctena Först. и F. rufa L., поскольку в лесных биоценозах ассоциации их муравейников могут занимать сотни гектаров, а биомасса достигать 100 кг на 1 га (Длусский, 1967).

В настоящее время известно, что слабой стороной широко используемых средств биологической борьбы с вредителями леса (микробиологические препараты и паразитические насекомые) является разовость их воздействия, причем их эффективность зависит от целого ряда факторов (Захаров, 2015). В отличие от таких средств применение рыжих лесных муравьев выделяется несколькими преимуществами: а) территориальность; б) эффективность воздействия на основных вредителей леса на своей кормовой территории; в) длительность лесозащиты в течение теплого сезона и способность поселений к саморазвитию; г) высокая стабильная плотность населения независимо от колебаний численности насекомых-филлофагов; д) мультифункциональная положительная ценотическая роль в лесу; е) комплементарность с другими хищными беспозвоноч- 
ными; ж) простота методов использования (Захаров, 2015).

Муравьи живут семьями (многолетними общинами) в гнездах (муравейниках), которые располагаются в пространстве определенным образом в зависимости от условий местообитания (Захаров, Саблин-Яворский, 1998). Оценка пространственного распределения поселений муравьев имеет первостепенное значение, поскольку без его учета невозможно использовать их в лесозащитных мероприятиях. Для выявления пространственного распределения поселений муравьев весьма перспективно использование геоинформационных систем (ГИС), в том числе гибридных ГИС (Батурин и др., 2012). Современное развитие гибридных ГИС позволяет проводить исследования удаленно через сеть интернет, подключая распределенные сервисы анализа и обработки пространственных данных, разработанные различными коллективами в соответствии со стандартами консорциумa Open Geospatial Consortium (http://www. opengeospatial.org/) к программному обеспечению.

Цель работы - на территории Байкальского региона выявить лесные участки с комплексами гнезд рыжих лесных муравьев и оценить уровень защищенности этих участков от насекомых-филлофагов с использованием гибридной ГИС.

\section{Материалы и методы}

Исходный материал получен в результате полевых работ в 2010 и 2014 гг. на территории Байкальского региона (рис. 1). Сбор муравьев осуществляли согласно общепринятой мирмекологической методике (Длусский, 1965). Применяли маршрутный метод с полосой 10 м. В ходе маршрутных учетов протяженностью от 1 до 3 км обнаружено 121 гнездо рыжих лесных муравьев. Из каж- дого муравейника (с купола) взяты пробы по 30-100 рабочих особей. Весь материал, использованный в этой работе, хранится в энтомологической коллекции ЦКП «Биоресурсный центр» Сибирского института физиологии и биохимии растений СО РАН (г. Иркутск). Для регистрации координат расположения гнезд муравьев применялись GPS-навигаторы Garmin GPS 12 и Garmin eTrex 30. Также во время полевых работ на нескольких лесных участках у каждого муравейника измеряли размеры основания купола.

В работе использованы два уровня защищенности лесных участков от насекомыхфиллофагов: лесной участок защищен от существенных повреждений филлофагами и не защищен. Участок считали защищенным, если и плотность поселения муравьев, и мощность гнездового комплекса равнялись минимально необходимым значениям или превышали их.

Одним из важных параметров, характеризующих способность муравьев эффективно защищать насаждения, служит плотность их поселения, т.е. среднее число гнезд, приходящихся на единицу площади (гектар) (Дмитриенко, Петренко, 1976). В последнее время при оценке способности комплекса муравейников защищать участок леса от насекомыхфиллофагов рекомендуется также использовать сумму площадей основания купола этих муравейников (Захаров, 2015), поскольку этот параметр отражает их мощность, т.е. способность охранять территорию леса определенной площади, а сама площадь основания купола муравейника является наиболее устойчивой размерной характеристикой гнезда. Нижний предел этого параметра - 6 м²/га, или, говоря иными словами, если сумма площадей основания купола всех гнезд исследуемого комплекса $\geq 6 \mathrm{~m}^{2} / г$, то участок леса 


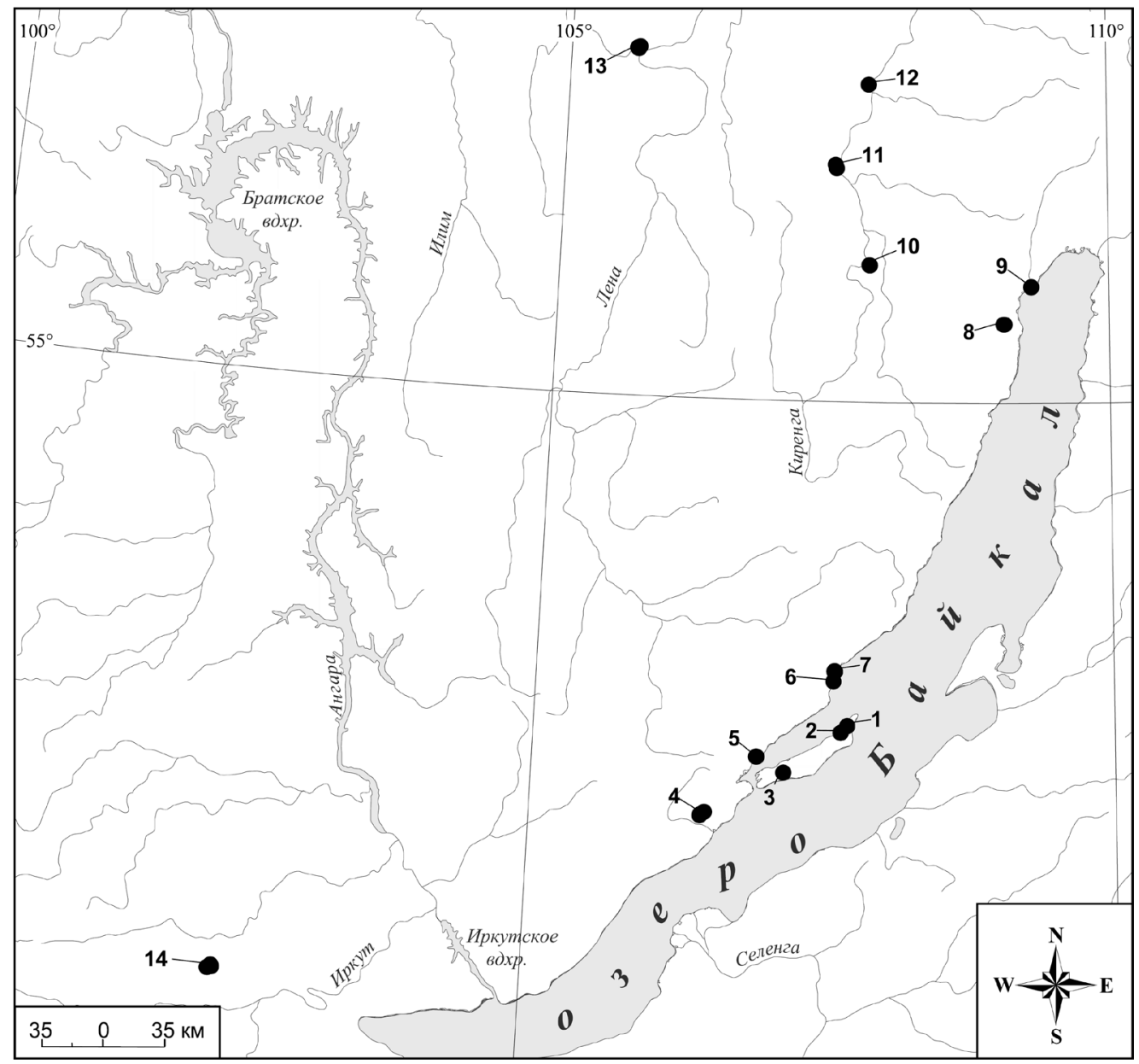

Рис. 1. Карта пунктов сбора рыжих лесных муравьев (проекция прямая коническая равнопромежуточная, Байкальский регион): 1 - окр. пос. Узуры, о. Ольхон, Иркутская область; 2 - окр. д. Халгай, о. Ольхон, Иркутская область; 3 - окр. д. Ялга, о. Ольхон, Иркутская область; 4 - окр. с. Еланцы, Ольхонский район, Иркутская область; 5 - окр. д. Курма, Ольхонский район, Иркутская область; 6 - недалеко от с. Онгурен, Ольхонский район, Иркутская область; 7 - окр. с. Онгурен, Ольхонский район, Иркутская область; 8 - окр. с. Байкальское, Северо-Байкальский район, Республика Бурятия; 9 - окр. г. Северобайкальск, Республика Бурятия; 10 - окр. пос. Улькан, Казачинско-Ленский район, Иркутская область; 11 - окр. д. Ключи, Казачинско-Ленский район, Иркутская область; 12 - окр. с. Ермаки, Казачинско-Ленский район, Иркутская область; 13 - окр. г. Усть-Кут, Иркутская область; 14 - окр. санатория «Аршан», Тункинский район, Республика Бурятия

Fig. 1. Map of the sampling locations of red wood ants (straight conical equidistant projection for the Baikal region): 1 - environs of the village of Uzury, Ol'khon island, Irkutsk oblast; 2 - environs of the village of Khalgay, Ol'khon island, Irkutsk oblast; 3 - environs of the village of Yalga, Ol'khon island, Irkutsk oblast; 4 - environs of the village of Elantsy, Ol'khonskiy district, Irkutsk oblast; 5 - environs of the village of Kurma, Ol'khonskiy district, Irkutsk oblast; 6 - at the village of Onguren, Ol'khonskiy district, Irkutsk oblast; 7 - environs of the village of Onguren, Ol'khonskiy district, Irkutsk oblast; 8 - environs of the village of Baykal'skoe, SeveroBaykal'skiy district, Republic of Buryatia; 9 - environs of the town of Severobaykal'sk, Republic of Buryatia; 10 - environs of the village of Ul'kan, Kazachinsko-Lenskiy district, Irkutsk oblast; 11 - environs of the village of Klyuchi, Kazachinsko-Lenskiy district, Irkutsk oblast; 12 - environs of the village of Ermaki, KazachinskoLenskiy district, Irkutsk oblast; 13 - environs of the town of Ust'-Kut, Irkutsk oblast; 14 - environs of "Arshan" resort, Tunkinskiy district, Republic of Buryatia 
можно считать защищенным от объедания насекомыми-филлофагами (Захаров, 2015). Само основание купола гнезда имеет форму, близкую к эллипсу. Поэтому площадь основания купола гнезда муравьев определяли по формуле

$$
S=\pi a b
$$

где $a$ - длина большой полуоси эллипса; $b-$ длина малой полуоси эллипса.

Выявление пространственного распределения поселений муравьев с помощью гибридной ГИС состояло из нескольких этапов. Сначала определяли лесные участки с гнездовыми комплексами. Потом рассчитывали плотность поселения муравьев на каждом выявленном участке леса и выбирали лесные участки с плотностью поселения муравьев, равной минимально необходимой плотности поселения или превышающей ее. Затем вычисляли мощность выбранных на первом этапе комплексов муравейников и оценивали уровень защищенности участков с выбранными гнездовыми комплексами от насекомых-филлофагов. На заключительном этапе устанавливали ландшафтное распределение исследованных лесных участков.

В качестве гибридной ГИС использовали геопортал Института динамики систем и теории управления СО РАН (http://geos.icc.ru), основанный на открытой и расширяемой архитектуре (Бычков и др., 2016). Он состоит из нескольких подсистем: а) подсистема ввода и редактирования пространственных данных, позволяющая создавать и редактировать таблицы с пространственными атрибутами (для визуализации пространственных данных используется сервис, называемый SMD Server, который реализует WMS стандарт); б) подсистема применения WPS сервисов, позволяющая производить запуск сервисов, выполнять конвертацию табличных данных в формат
SHAPE, обеспечивать передачу данных в соответствии со стандартом WPS и сохранять результаты работы сервисов; в) WPS-сервисы пространственного анализа территорий (например, сервис построения различных тематических карт и сервисы пространственного статистического анализа). Новые сервисы могут быть разработаны на любой платформе, на любом языке программирования и любыми разработчиками в соответствии со стандартом WPS, в том числе на основе других сервисов.

Расчет плотности поселений состоял из нескольких шагов: а) создание векторного точечного слоя мест находок гнезд для каждого вида; б) выявление лесных участков с комплексами муравейников; в) расчет самой плотности поселения.

Для создания векторных точечных слоев мест находок гнезд в рамках геопортала строили таблицы, содержащие следующие поля: координаты географического положения гнезда, дата сбора, уникальный номер гнезда и вид муравьев. Данные в созданной таблице вводили и редактировали с помощью сгенерированного пользовательского интерфейса.

Лесные участки выделяли по пространственному расположению гнезд. Муравейники объединяли в комплексы, если расстояние между ними составляло не более 150 м, поскольку длина дорог от гнезда иногда может превышать 100 м (Захаров, 1972). При этом от крайних гнезд отсчитывали около 25 м, т.е. брали средний радиус защитного действия муравейников (Дмитриенко, Петренко, 1976).

Выделение участков производили с помощью средств анализа таблиц геопортала. К пространственным данным применяли систему специальных фильтров. В результате работы этой системы стали известны лесные 
участки с комплексами муравейников, площади этих участков и число гнезд в каждом комплексе. На последнем шаге выполняли расчет плотности поселения как отношения количества гнезд к площади участка проведения работ.

Расчет мощности комплекса гнезд с помощью гибридной ГИС состоял из нескольких процедур. Сначала рассчитывали площадь основания купола каждого муравейника по отдельности в сервисе гибридной ГИС, где каждое гнездо имело уникальный номер. Далее определяли, к какому комплексу принадлежит муравейник, с помощью SQL-запроса, в котором задавали условие, что точки (муравейники) из слоя мест находок лежат внутри полигонов (участков) из слоя областей проведения полевых работ. Результат запроса представляли в виде списка, в котором каждый муравейник располагался на определенном участке. Затем эти данные переносили обратно в сервис, где уже производили сортировку гнезд по комплексам и окончательный расчет мощности гнездового комплекса.

Поскольку ландшафтные условия существенно влияют на пространственное распределение поселений муравьев, на последнем этапе выявлялось ландшафтное распределение исследованных лесных участков. Для этого использовали векторный слой «Ландшафты Байкальского региона» геопортала, созданный на основе изданной карты «Ландшафты юга Восточной Сибири» (Михеев, Ряшин, 1977). Легенда ландшафтного слоя разработана на основе таксономической системы типологических иерархических подразделений геосистем юга Восточной Сибири, при этом в анализе присутствовал уровень геомов, которые являются наиболее крупными подразделениями типологического порядка и несут в себе черты региональной неодно- родности территории (Сочава, 1978). Кроме того, выбор обусловлен тем, что геом считают стержневой картируемой категорией, о которой используемая карта дает наиболее полное представление (Сочава, 1978). Анализ проводился с помощью SQL-запроса, в котором задавали условие, что полигоны (участки) из слоя областей проведения полевых работ лежат внутри полигонов (ландшафтов на уровне геомов) из ландшафтного слоя. Результат запроса представляли в виде списка, в котором каждый участок находился в определенном ландшафте.

\section{Результаты и обсуждение}

В результате обработки сборов выяснено, что 101 гнездо принадлежало F. aquilonia и 20 гнезд -F. lugubris. Ранее уже отмечалось, что эти виды являются самыми многочисленными представителями муравьев группы $F$. rufa в Байкальском регионе (Антонов, Плешанов, 2008, 2011). В ходе пространственного анализа установлено, что 102 гнезда (88 муравейников $F$. aquilonia и $14-F$. lugubris) cфopмировали комплексы муравейников, которые располагались на 18 лесных участках (табл. 1). При этом 15 комплексов гнезд принадлежали F. aquilonia, а три -F. lugubris.

На первом этапе расчеты показали, что самая большая плотность поселения была на четырех участках возле пос. Узуры, с. Еланцы и с. Онгурен. Стоить отметить, что площади участков «Еланцы_1», «Еланцы_2» и «Онгурен_3» существенно меньше одного гектара. Следовательно, вычисленные значения плотностей поселения на этих участках оказались интерполированными. На остальных участках плотность поселения оказалась ниже (табл. 1). Из литературы известны несколько нижних пороговых значений данного параметра в зависимости от типа леса и вида насекомого-филлофага. Так, при наличии 9 
Таблица 1. Основные параметры комплексов гнезд муравьев и обследованных участков леса

Table 1. Basic parameters of the complexes of ants' nests and the examined forest plots

\begin{tabular}{|c|c|c|c|c|c|}
\hline $\begin{array}{c}\text { Обследованный } \\
\text { участок леса* }\end{array}$ & $\begin{array}{c}\text { Ландшафты } \\
\text { (геомы)** }^{*}\end{array}$ & Число гнезд & $\begin{array}{c}\text { Площадь } \\
\text { участка, га }\end{array}$ & $\begin{array}{c}\text { Плотность } \\
\text { поселения, } \\
\text { гнезд/га }\end{array}$ & $\begin{array}{c}\text { Высота над ур. } \\
\text { м., м }\end{array}$ \\
\hline Узуры & I & 7 & 0,95 & 7 & $623-625$ \\
\hline Халгай & I & 10 & 2,20 & 5 & $552-574$ \\
\hline Ялга & I & 4 & 0,90 & 4 & $772-806$ \\
\hline Еланцы_1 & II & 3 & 0,53 & 6 & $644-647$ \\
\hline Еланцы_2 & II & 2 & 0,23 & 9 & $614-615$ \\
\hline Курма_1 & I & 8 & 3,51 & 2 & $678-705$ \\
\hline Курма_2 & I & 2 & 0,52 & 4 & $651-659$ \\
\hline Онгурен_1 & I & 2 & 0,94 & 2 & $551-574$ \\
\hline Онгурен_2 & I & 16 & 3,49 & 5 & $541-599$ \\
\hline Онгурен_3 & I & 3 & 0,50 & 6 & $530-538$ \\
\hline Северобайкальск & III & 7 & 1,65 & 4 & $483-489$ \\
\hline Улькан & IV & 9 & 2,15 & 4 & $432-454$ \\
\hline Ключи & IV & 6 & 2,73 & 2 & $341-454$ \\
\hline Ермаки & $\mathrm{V}$ & 5 & 1,15 & 4 & $335-338$ \\
\hline Аршан_1 & VI & 7 & 2,04 & 3 & $1081-1121$ \\
\hline Аршан_2 & VI & 3 & 1,71 & 2 & $949-968$ \\
\hline Аршан_3 & VI & 3 & 1,32 & 2 & $952-972$ \\
\hline Аршан_4 & VII & 5 & 2,44 & 2 & $872-885$ \\
\hline
\end{tabular}

Примечание: * название участков дано по близлежащему населенному пункту (см. рис. 1); ** I - горно-таежные сосновые; II - подгорные подтаежные сосновые; III - межгорных понижений и долин таежные лиственничные редуцированного развития; IV - среднетаежные лиственничные (на равнинах); V - подтаежные (на приподнятых равнинах и плато) лиственничные и сосновые; VI - горно-таежные темнохвойные редуцированного развития; VII горно-таежные темнохвойные ограниченного развития.

гнезд $F$. polyctena на 1 га леса повреждение хвои лжегусеницами соснового пилильщика (Diprion pini L.) равнялось 0-10 \%, при 4 гнездах $-25 \%$, а при отсутствии муравьев - $100 \%$ (Otto, 1967). Расчеты В.К. Дмитриенко и Е.С. Петренко (1976) показали, что для защиты 1 га леса от серой лиственничной листовертки (Zeiraphera griseana Hbn.) необходимо не менее 5-8 крупных муравейников северного лесного муравья (F. aquilonia), а для защиты 1 га пихтача зеленомошного от опасных насекомых-филлофагов - 30-35 муравейников этого вида. Таким образом, исходя из приведенных данных, минимально необходимая плотность - 5 крупных гнезд рыжих лесных муравьев на 1 га леса. Этому требованию удовлетворяют всего шесть участков («Узуры», «Халгай», «Еланцы_1», «Еланцы_2», «Онгурен_2»и «Онгурен_3»).

На втором этапе рассчитывали мощности комплексов гнезд на отобранных шести лесных участках (плотность поселения $\geq 5$ гнезд/га). В результате выявлено четыре участка («Узуры», «Халгай», «Онгурен_2» и «Онгурен_3»), на которых мощность гнездового комплекса больше $6 \mathrm{~m}^{2} /$ га, и их можно считать защищенными от существенных повреждений насекомыми-филлофагами (табл. 2). Остальные участки не могли считаться защищенными, поскольку либо плот- 
Таблица 2. Параметры комплексов гнезд муравьев на участках с плотностью поселения $\geq 5$ гнезд/га

Table 2. Parameters of complexes of the ants' nests in the examined forest plots with colony density $\geq 5$ nests/ha

\begin{tabular}{|c|c|c|c|}
\hline Вид муравья & Обследованный участок & $\begin{array}{c}\text { Площадь } \\
\text { комплекса гнезд*, } \text { м }^{2}\end{array}$ & $\begin{array}{c}\text { Мощность } \\
\text { комплекса гнезд, }{ }^{2} / \text { га }\end{array}$ \\
\hline Formica lugubris & Узуры & 9,24 & 9,73 \\
F. aquilonia & Халгай & 18,21 & 8,28 \\
F. lugubris & Еланцы_1 & 2,48 & 4,68 \\
F. aquilonia & Еланцы_2 & 0,37 & 1,61 \\
F. aquilonia & Онгурен_2 & 43,71 & 12,52 \\
F. aquilonia & Онгурен_3 & 14,41 & 28,82 \\
\hline
\end{tabular}

Примечание: * сумма площадей основания купола всех гнезд комплекса.

ность поселения была низкой, либо мощность гнездового комплекса - недостаточной.

Bсе участки, которые защищены от существенных повреждений насекомымифиллофагами, расположены на территории Прибайкальского национального парка. При этом комплекс муравейников на участке «Онгурен_2» находился в хорошем состоянии и активно развивался (много отводков), поскольку располагался в малонаселенном и труднодоступном районе и далеко от основных туристических маршрутов. Поэтому все муравейники на этом участке сохранились целыми и большинство имели крупные размеры. Этот гнездовой комплекс может служить базой для взятия искусственных отводков. Напротив, комплексы муравейников на участках «Узуры» и «Халгай» могут деградировать (почти половина гнезд повреждено) из-за интенсивной рекреационной нагрузки, поскольку находятся на одном из самых популярных туристических маршрутов. Комплексы муравейников на участках «Еланцы_1» и «Еланцы_2» также могут деградировать, ибо расположены в небольшом изолированном лесном массиве, который интенсивно вырубается.

Необходимо сказать несколько слов о том, для чего нужны искусственные отводки.
Известно, что видов муравьев, являющихся достаточно эффективными как энтомофаги, не так много; прежде всего это рыжие лесные муравьи, луговой муравей (Formica pratensis Retz.), песчаный муравей (F. cinerea Mayr), тонкоголовый муравей ( $F$. exsecta Nyl.) и красноголовый муравей (F. truncorum Fabr.) (Захаров, 2015). Искусственные отводки в основном необходимы для переселения таких муравьев в возникающие и действующие очаги массового размножения листо- и хвоегрызущих вредителей леса, в ранее покинутые ими из-за разных внешних факторов (особенно антропогенного) территории, которые снова стали пригодны для проживания муравьев, и на новые лесные участки, которые также пригодны для проживания муравьев. Поскольку в один из этапов комплекса мероприятий по искусственному переселению муравьев входит подбор комплекса маточных муравейников, который должен быть достаточно большим, чтобы из него можно было взять количество отводков, необходимое для создания как минимум одного полноценного поселения на новом месте (Захаров, 2015), то гнездовой комплекс на участке «Онгурен_2», имеющий 13 крупных гнезд, из которых можно брать отводки, подходит на роль комплекса маточных муравейников. 
Геоинформационный анализ ландшафтного распределения выявленных участков показывает, что существенное число участков, включая участки возле п. Узуры, д. Халгай и c. Онгурен, находится в горно-таежном сосновом ландшафте (табл. 1). Участки «Еланцы_1» и «Еланцы_2», на которых гнезда имеют небольшие размеры, расположены в подгорном подтаежном сосновом ландшафте. Участок «Аршан_2», на котором отмечена самая низкая плотность поселения (меньше двух гнезд на один гектар), находится в горно-таежном темнохвойном ландшафте редуцированного развития.

Интересно отметить, что самые крупные комплексы муравейников обнаружены в горно-таежных сосновых лесах. Этот тип ландшафта в основном распространен в пределах юга Иркутской области и центральной части Республики Бурятия (рис. 2). Площадь горно-таежных сосновых лесов составляет около 67,3 тыс. км², или всего 4,32 \% территории Байкальского региона. Однако, несмотря на небольшую площадь, которую покрывают горно-таежные сосновые леса, стоит отметить, что они занимают значительную территорию в промышленно развитых частях Байкальского региона.

В последнее время использование муравьев в лесозащитных мероприятиях, прежде всего их переселение, стало крайне мало изза экологического кризиса и, применительно к России, кризиса лесного хозяйства, развивающегося и по настоящее время. При этом многие исследователи ставят под сомнение эффективность муравьев в лесозащите, но такие оценки основаны на неполных данных (Захаров, 2015). Во-первых, учеты добычи неполны, поскольку значительную часть белковой пищи муравьи приносят в зобиках (Horstmann, 1974). Во-вторых, не учитываются гусеницы, погибшие после контакта с му- равьями, но не собранные ими (Дмитриенко, Петренко, 1976). Наконец, лесозащитная роль муравьев не сводится только к физическому уничтожению вредителя. Они, например, являются фактором регулярного беспокойства, мешая тем самым нормальному питанию гусениц и откладке яиц самками вредителя (Gösswald, 1990).

Действительно, муравьи не в состоянии остановить развитие вспышки массового размножения вредителя в масштабах его популяции, поскольку они контролируют лишь доли процента ареала вредителя, и эти доли повсеместно сокращаются в результате нарастающего антропогенного пресса (Захаров, 2015). Основная роль муравьев как энтомофагов заключается в защите находящихся на их кормовых участках деревьев от дефолиации опаснейшими насекомымифиллофагами. С этой задачей рыжие лесные муравьи справляются крайне успешно, о чем свидетельствуют данные, приведенные в многочисленной литературе (Gösswald, 1951; Otto, 1970 и др.).

\section{Заключение}

Муравьи F. aquilonia и F. lugubris являются самыми многочисленными представителями группы Formica rufa на территории Байкальского региона. В результате обработки сборов определено, что 101 гнездо принадлежало $F$. aquilonia и 20 гнезд $F$. lugubris. В ходе пространственного анализа выявлено 18 лесных участков с комплексами муравейников этих видов. Из них только лесные участки «Узуры», «Халгай», «Онгурен_2»и «Онгурен_3», расположенные в горно-таежном сосновом ландшафте (занимающем 4,32 \% территории Байкальского региона), защищены от существенных повреждений насекомыми-филлофагами. Самой низкой плотностью поселений му- 


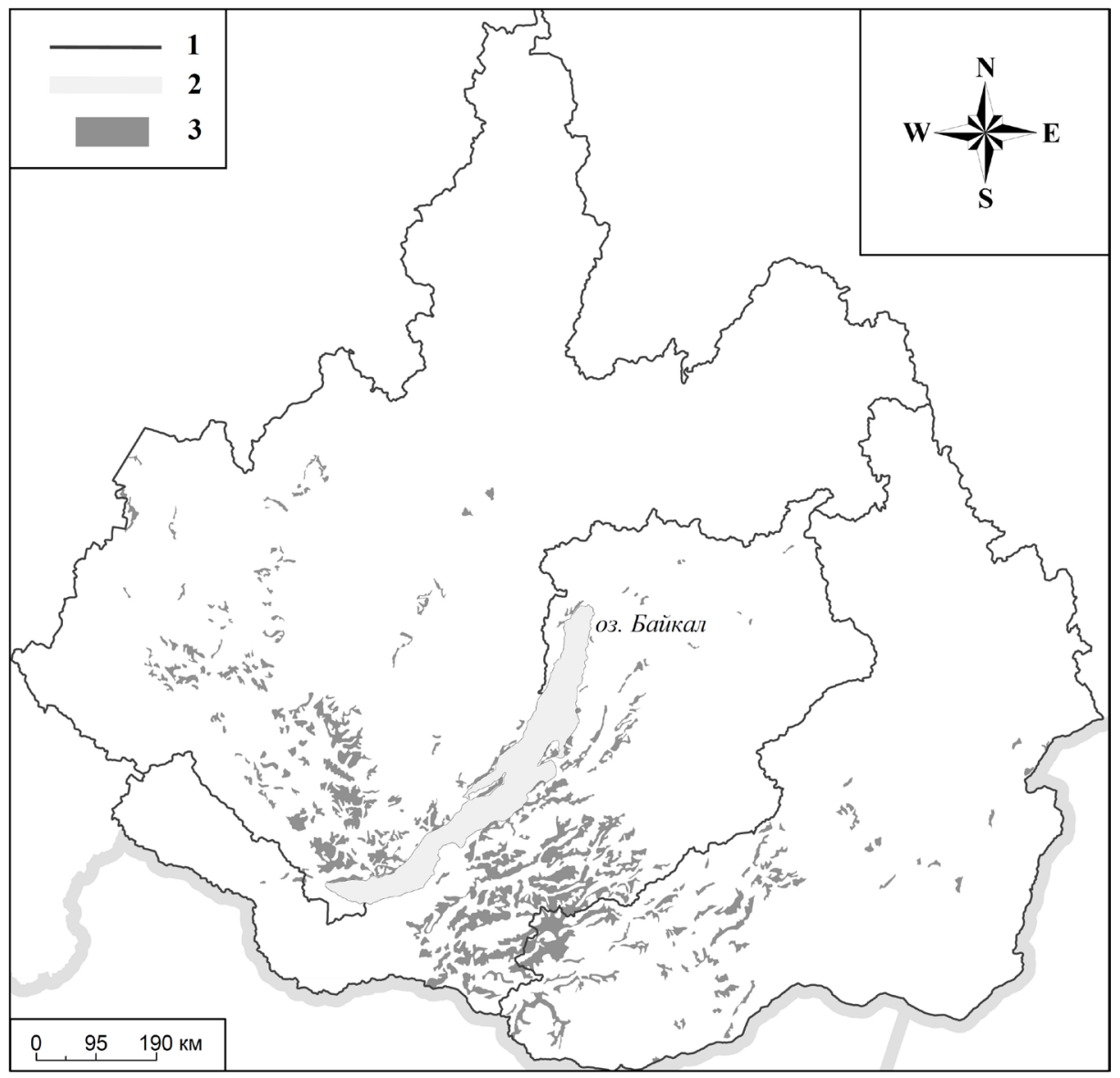

Рис. 2. Карта-схема распространения горно-таежных сосновых лесов на территории Байкальского региона: 1 - административные границы; 2 - государственные границы; 3 - горно-таежный сосновый ландшафт

Fig. 2. A diagrammatic map of the mountain taiga pine forest range in the Baikal region: 1 - administrative boundaries; 2 - state borders; 3 - mountain taiga pine forest

равьев отличался участок «Аршан_2», расположенный в горно-таежном темнохвойном ландшафте редуцированного развития. Развитие крупных гнездовых комплексов возле с. Онгурен может объясняться незначительным антропогенным прессом и их расположением в крупных лесных массивах. При этом комплекс муравейников на участке «Онгурен_2» может служить базой для взятия искусственных отводков.

Применение гибридной ГИС, основанной на современных стандартах, дает возможность быстро и эффективно выявлять и анализировать пространственное распределение поселений рыжих лесных муравьев.

\section{Благодарности / Acknowledgements}

Работа выполнена в рамках программы ФНИ СИФИБР CO РАН, проект № AAAA-A17-117011810101-8.

The study was conducted within the project No. AAAA-A17-117011810101-8. 


\section{Список литературы / References}

Антонов И.А., Плешанов А.С. (2008) Ландшафтно-экологические комплексы муравьев Байкальской Сибири. Сибирский экологический журнал, 15 (1): 53-57 [Antonov I.A., Pleshanov A.S. (2008) Landscape ecological complexes of ants in Baikalian Siberia. Siberian Ecological Journal [Sibirskii Ekologicheskii Zhurnal], 15 (1): 53-57 (in Russian)]

Антонов И.А., Плешанов А.С. (2011) Эколого-географические особенности мирмекофауны Байкальского региона. Вестник Бурятского государственного университета, 4: 104-108 [Antonov I.A., Pleshanov A.S. (2011) Ecological-geographical features of myrmicafauna of Baikal region. Bulletin of the Buryat State University [Vestnik Buryatskogo gosudarstvennogo universiteta], 4: 104-108 (in Russian)]

Батурин В.А., Будням С., Малтугуева Н.С., Федоров Р.К. (2012) Оценка и моделирование загрязнения атмосферного воздуха в г. Улан-Батор. Программные системы: теория и приложения, 3 (5): 81-91 [Baturin V.A., Budnyam S., Maltugueva N.S., Fedorov R.K. (2012) Evaluation and modeling of air pollution in Ulaanbaatar. Program Systems: Theory and Applications [Programmnye sistemy: teoriya i prilozheniya], 3 (5): 81-91 (in Russian)]

Бычков И.В., Ружников Г.М., Федоров Р.К., Шумилов А.С. (2016) Система планирования и выполнения композиций веб-сервисов в гетерогенной динамической среде. Вычислительные технологии, 21 (6): 18-35 [Bychkov I.V., Rugnikov G.M., Fedorov R.K., Shumilov A.S. (2016) System for dynamic execution of composition services in the heterogeneous environment. Computational Technologies [Vychislitel'nye tekhnologii], 21 (6): 18-35 (in Russian)]

Длусский Г.М. (1965) Методы количественного учета почвообитающих муравьев. Зоологический журнал, 44 (5): 716-727 [Dlussky G.M. (1965) Methods of conducting quantitative census of soil dwelling ants. Zoological Journal [Zoologicheskiy zhurnal], 44 (5): 716-727 (in Russian)]

Длусский Г.М. (1967) Муравьи рода Формика. М., Наука, 236 с. [Dlussky G.M. (1967) The ants of the genus Formica. Moscow, Nauka, 236 p. (in Russian)]

Дмитриенко В.К., Петренко Е.С. (1976) Муравьи таежных биоценозов Сибири. Новосибирск, Наука, 220 c. [Dmitrienko V.K., Petrenko E.S. (1976) Ants of the taiga ecosystems in Siberia. Novosibirsk, Nauka, 220 p. (in Russian)]

Захаров А.А. (1972) Внутривидовые отношения у муравьев. М., Наука, 216 с. [Zakharov A.A. (1972) Intraspecific relations of ants. Moscow, Nauka, 216 p. (in Russian)]

Захаров А.А. (2015) Муравьи лесных сообществ, их жизнь и роль в лесу. М., Товарищество научных изданий КМК, 404 с. [Zakharov A.A. (2015) Ants of forest communities, their life and role in the forest. Moscow, KMK Scientific Press, 404 p. (in Russian)]

Захаров А.А., Саблин-Яворский А.Д. (1998) Муравьи в изучении биологического разнообразия. Успехи современной биологии, 118 (3): 246-264 [Zakharov A.A., Sablin-Yavorsky A.D. (1998) Ants in studying biological diversity. Advances in Modern Biology [Uspekhi sovremennoi biologii], 118 (3): 246-264 (in Russian)]

Михеев В.С., Ряшин В.А. (1977) Ландшафты юга Восточной Сибири (карта). М 1:1 500000. М., ГУГК, 4 л. [Mikheev V.S., Ryashin V.A. (1977) Landscapes of the south of East Siberia. Map $1: 1500$ 000. Moscow, GUGK, 4 p. (in Russian)]

Плешанов А.С. (1982) Насекомые-дефолианты лиственничных лесов Восточной Сибири. Новосибирск, Наука, 209 с. [Pleshanov A.S. (1982) The insect-defoliants of larch forests of Eastern Siberia. Novosibirsk, Nauka, 209 p. (in Russian)]

$$
-396-
$$


Природные ресурсы, хозяйство и население Байкальского региона. (2009) Серия из 100 карт. Антипов А.Н., Батуев А.Р., Корытный Л.М. (отв. ред.) Иркутск, Изд-во Ин-та географии им. В.Б. Сочавы СО РАН [Natural resources, economy and population of the Baikal region. (2009) Series of 100 maps. Antipov A.N., Batuev A.R., Korytnyy L.M. (Eds.) Irkutsk, VB Sochava Institute of Geography (in Russian)]

Сочава В.Б. (1978) Введение в учение огеосистемах. Новосибирск, Наука, 320 c. [Sochava V.B. (1978) An introduction to the theory of geosystems. Novosibirsk, Nauka, 320 p. (in Russian)]

Gösswald K. (1951) Die rote Waldameise im Dienste der Waldhygiene. Forstwirtschaftliche Bedeutung, Nutzung, Lebensweise, Zucht, Vermehrung und Schutz. Lüneburg, Metta Kinau Verlag, 160 s. (in German)

Gösswald K. (1990) Die Waldameise. Band 2. Die Waldameise im Ökosystem Wald, ihr Nutzen und ihre Hege. Wiesbaden, AULA Verlag, 510 s. (in German)

Horstmann K. (1974) Untersuchungen über den Nahrungserwerb der Waldameisen (Formica polyctena Foerster) im Eichenwald. III. Jahresbilanz. Oecologia, 15 (2): 187-204 (in German)

Niu J.Z., Hull-Sanders H., Zhang Y.X., Lin J.Z., Dou W., Wang J.J. (2014) Biological control of arthropod pests in citrus orchards in China. Biological Control, 68: 15-22

Otto D. (1967) Zur Schutzwirkung von Formica polyctena Först in einem Massenvermehrungebiet von Diprion pini L. Zeitschrift für Angewandte Entomologie, 54 (1): 167-172 (in German)

Otto D. (1970) Einige grundsätzliche Feststellungen zur Einsatzmöglichkeit von Formica polyctena Foerst. im Forstschutz. Biol. Bek. Meth. von Forstschádl. Tagungsber, 110: 87-108 (in German)

Ramos R.S., Picanço M.C., Santana P.A., Silva E.M., Bacci L., Gonring A.H.R., Silva G.A. (2012) Natural biological control of lepidopteran pests by ants. Sociobiology, 59 (4): 1389-1399

Żmihorski M. (2010) Distribution of red wood ants (Hymenoptera: Formicidae) in the clear-cut areas of a managed forest in Western Poland. Journal of Forest Research, 15 (2): 145-148 